функциональные нарушения зубочелюстного аппарата, возникающие в результате поражения, соответственно факт регистрации травмы, как и прогноз реабилитации в подобных случаях базируется лишь на анатомическом критерии, который не всегда обеспечивает соответствующий уровень объективности в ходе оценки последствий дорожно-транспортных происшествий. Наиболее перспективный метод оценки тяжести травм максило-фацилярной области с учетом параметров анатомических и функциональных нарушений по системе MFISS ограничен отсутствием унифицированного подхода к диагностике различных видов травм зубочелюстного аппарата, особенностями механизма формирования переломов ЧЛО в результате ДТП, привязанностью к критериям AIS- 90 в качестве базового параметра оценки, и ошибками верификации патологических изменений стоматологического статуса еще на этапе первичной диагностики пострадавших, поэтому поиск и разработка оптимального метода оценки травм зубочелюстной аппарата с целью использования его в ходе судебно-медицинских и судебно-стоматологических экспертиз остается открытым научно практическим вопросом современной стоматологии и судебной медицины.

Ключевые слова: травмы челюстно-лицевой области, дорожно-транспортные происшествия.

\title{
POSSIBILITIES OF MAXILLOFACIAL INJURY'S PARAMETERS OBJECTIFICATION
}

\author{
Brehlichuk P. P., Kostenko Y. Y., Goncharuk-Khomyn M. Y.
}

Resume. According to the results of different researches, the prevalence of maxillofacial area injuries during road traffic accidents ranges from $17 \%$ to $94 \%$. Most of the victims with maxillofacial region alterations after such accidents have combined injuries $(61 \%)$, and less than half have isolated injuries. In order to provide adequate rehabilitation of such patients with a tooth-jaw apparatus injuries, should be conducted comprehensive medical treatment that in $77 \%$ of cases includes surgical iatrogenic intervention. However, during the analysis of existing methodologies to assess the damages of maxillofacial area, it was found that the most of these approaches didn't capture functional disorders of the teeth-jaw system after road traffic accidents, respectively the registration of injuries in such cases is based only on anatomical criteria, which does not always provide the appropriate level of objectivity during the evaluation of the accidents post effects. The most promising algorithm for assessing the severity of maxillofacial injuries with regard to anatomic and functional changes included in the MFISS system, that is also limited to the lack of a unified approach for the diagnostics of different types of tooth-jaw apparatus injuries, especially to the mechanism of formation of maxillofacial fractures during traffic accident, adherence to the AIS- 90 criteria as a basic estimation parameter and due to the verification errors of dental status lesions at the stage of initial diagnostics of the victims. That is why the research and development of the optimal method for assessing tooth-jaw apparatus injuries that can be used during forensic medical and forensic dental examinations is an open scientific and practical aspect of modern dentistry and forensic medicine.

Key words: injuries maxillofacial area of road accidents.

УДК: $340.62: 616.742-001$

\section{НЕВИПРАВНЕ ЗНІВЕЧЕННЯ ОБЛИЧЧЯ - СУДОВО-МЕДИЧНІ ТА ЮРИДИЧНІ АСПЕКТИ}

\author{
С.Л. Л. Голубович ${ }^{1}$, А. Л. Голубович ${ }^{2}$, П. Л. Голубович ${ }^{2}$, \\ М. Д. Зубко ${ }^{1}$, А. В. Куртєв² \\ Запорізький державний медичний університет ${ }^{1}$ \\ Запорізьке обласне бюро судово-медичної експертизи ${ }^{2}$
}

Резюме. Швидкоплинні зміни в економічному, політичному і суспільному житті диктують потребу змін і у правовій сфері, де працюють не тільки юристи а й судово-медичні експерти, основна робота яких полягає у допомозі судово-слідчим органам у встановленні істини в конкретних справах, коли скоєні злочини проти життя, здоров'я, честі чи гідності людини. В роботі аналізуються труднощі, з якими стикається судово-медичний експерт при визначенні ступеня тяжкості спричинених тілесних ушкоджень за критерієм «невиправне знівечення обличчя» і пропонуються шляхи усунення протиріч.

Ключові слова: судово-медична експертиза, невиправне знівечення обличчя, ступінь тяжкості тілесних ушкоджень

ВСТУП. Найбільш часто судово-медичним експертам доводиться мати справу з потерпілими особами, особливо з приводу спричинення їм тілесних ушкоджень. Цією публікацією ми долучаємося до проблеми піднятої у публікаціях А.Х. Завальнюка зі співавторами $[1,2]$ в яких автори пропонують внесення корективів у існуючи правила кваліфікації тяжкості тілесних ушкоджень.

Судово-медичне визначення ступеня тяжкості спричинених тілесних ушкоджень проводиться згідно 3 Кримінальним та Кримінально-процесуальним кодексами України [3] і Правилами судово-медичного визначення ступеня тяжкості тілесних ушкоджень [4]. На жаль ці правила не відрізняються читкістю формулювань і однозначністю трактувань характеристик тих чи інших критеріїв.

Особливо це стало помітним після прийняття «Закону України про адвокатуру та адвокатську діяльність» [5] (поточна редакція від 06. 02.2015p) та останнього редагування Кримінально процесуального кодексу України 
(від 01.01.2013p) [3]. Правила ж судово-медичної експертизи затверджені наказом МОЗ України від 17 січня 1995 року № 6 [4], залишаються незмінними вже понад 20 років.

Зокрема за останні роки почастішали випадки повернення судовими інстанціями «Висновків експерта», так як суд не задовольняє визначення ступеня тяжкості судово-медичними експертами у випадках спричинення потерпілій особі тілесних ушкоджень за ознакою «Невиправне знівечення обличчя». Згідно «Правил» [4] невиправне знівечення обличчя віднесене до ознак тяжкого тілесного ушкодження (П. 2.1.8). Разом з тим вказано, що судово-медичний експерт не кваліфікує ушкодження обличчя як знівечення, оскільки це поняття не є медичним. Він визначає вид ушкодження, його особливості і механізм утворення, встановлює чи є це ушкодження виправним або невиправним.

Мета роботи. Проаналізувати судово-медичні та юридичні підходи до вирішуваного питання і запропонувати шляхи усунення протиріч.

Автори «Правил» визначаючи, що знівечення не є медичним терміном, вказують, що судово-медичний експерт не кваліфікує цю ознаку. Відразу виникає питання - хто ії̈ кваліфікує? в інструкції цього не вказано.

Відповідь на перше питання умовно міститься у коментарі до Кримінального кодексу України, де зазначено, що поняття знівечення визначає суд чи (інколи) слідчий. 3 цього пояснення не повною мірою зрозуміло яким чином суд та слідчий це роблять, коли та спираючись на які критерії.

Відомо, що ступінь тяжкості тілесних ушкоджень встановлюється судово-медичним експертом за результатами проведення експертизи. Ані у «Правилах» [4], ні у кодексах напряму не вказано, що існують випадки коли ступінь тяжкості тілесних ушкоджень встановлюється іншими особами (чи організаціями) із переліком цих випадків.

Вбачається, що суб'єкт що проводить розслідування не наділений процесуальним правом встановлення ступеня тяжкості тілесних ушкоджень самостійно, та вирішує вказане питання виключно шляхом проведення судово-медичної експертизи через те, що він не володіє необхідними спеціальними знаннями в галузі медицини.

Жоден інший експерт, окрім судово-медичного, не наділений повноваженнями встановлення ступеня тяжкості тілесних ушкоджень. Механізму делегування повноважень експерта представникам судово-слідчих органів в доступних юридичних документах виявлено не було.

Ймовірно вважається, що суддя (слідчий), як особа, що не володіє спеціальними знаннями в галузі медицини та медико-біологічних наук, спираючись виключно на свої внутрішні переконання, щодо загальнолюдських естетичних критеріїв про нормальну анатомічну будову та функцію обличчя, визначивши наслідки зовнішнього травматичного впливу та отримавши висновок експерта про їх невиправність виносить рішення про зміну кваліфікації та оцінки тяжкості тілесних ушкоджень за досліджуваним критерієм «знівечення».

Виявляється, що в даному випадку стосовно однієї і тої самої події під час досудового та судового слідства потерпілому встановлюється два різних ступеня тяжкості тілесних ушкоджень та, відповідно, 3 різним ступенем відповідальності особи, яка це ушкодження спричинила. Перший раз на етапі досудового слідства, наприклад легкі тілесні ушкодження, що спричинили короткочасний розлад здоров'я із зазначенням механізму та факту невиправності наслідків травми.

Згідно ст. 291 УПК України, в якій вказано, що має містити обвинувальний акт, зокрема ч.5 зазначає [3], що обвинувальний акт передбачає кваліфікацію кримінального правопорушення з посиланням на положення закону і статті (частини статті), та ч.7, що потребує визначення шкоди, завданої кримінальним правопорушенням. Тобто на момент складання обвинувального акту, слідчий має лише результати судово-медичної експертизи про спричинення потерпілій особі легкого тілесного ушкодження або ушкодження середньої тяжкості.

Суддя ж визначаючи межі судового розгляду, керується ст. 337 КПК України, де ч.1[3] зазначено, що судовий розгляд проводиться лише стосовно особи, якій висунуте обвинувачення, і лише в межах висунутого обвинувачення відповідно до обвинувального акта, крім випадків передбачених цією статтею. Частина ж 3 цієї статті зазначає, що з метою ухвалення справедливого судового рішення та захисту людини і їі основоположних свобод суд має право вийти за межі висунутого обвинувачення, зазначеного в обвинувальному акті, лише в частині зміни правової кваліфікації кримінального правопорушення, якщо це покращує становище особи, стосовно якої здійснюється кримінальне провадження.

3 коментаря до Кримінального кодексу України, всупереч результатам раніше проведеної експертизи, слідчий під час досудового слідства чи суддя у процесі судового розгляду вдруге кваліфікує ті ж самі тілесні ушкодження вже як «тяжкі» за ознакою невиправності знівечення обличчя.

Але ж можливості судового розгляду обмежені: а) за колом осіб); б) за змістом обвинувачення. Розгляд справи в суді проводиться тільки щодо обвинувачених і по тому обвинуваченню, щодо якого винесена постанова судді про призначення судового засідання (ч. 1 ст. 337 КПК) [3]. Суд не може розглядати справу стосовно осіб, яким не пред'явлено звинувачення. Суд не вправі вийти за межі обвинувачення, щодо якого суддею було призначено судове засідання. При порушенні цих правил вирок підлягає скасуванню.

Встановленя меж судового розгляду продиктовано задачею гарантувати законний порядок притягнення до кримінальної відповідальності, достовірне встановлення всіх обставин справи і право обвинуваченого на захист. 
Проводячи судовий розгляд у межах обвинувачення, щодо якого призначено судовий розгляд, суд може, однак, не погодитися з обвинуваченням - виправдати підсудного або змінити обвинувачення, тобто винести обвинувальний вирок по іншому звинуваченню.

Зміна обвинувачення в суді відповідно до ч. 2 ст. 337 КПК та ст.338 КПК [3] допускається, якщо під час розгляду встановлені нові фактичні обставини кримінального правопорушення, у вчиненні якого обвинувачується особа. Ця зміна може бути зроблена лише прокурором, але прокурор не може змінювати ступінь тяжкості тілесного ушкодження на основі визнання невиправного знівечення обличчя. Таким чином утворюється замкнене коло з якого слід знайти вихід.

Особливо контраст з визначення ступеня тяжкості та його зміни є помітним при дорожньо-транспортних пригодах, коли легкі тілесні ушкодження відносяться до адміністративних правопорушень, а середньої тяжкості та тяжкі до кримінальних (згідно ст.186 КК України) [3].

Саме поняття «знівечення» не має визначення законодавцем, та не має чітких та науково обгрунтованих критеріїв. Майже завжди існує загроза визначення поняття виходячи не лише з його характеру та локалізації, а й зі статі та віку потерпілої особи, що суперечить принципам судово-медичного встановлення ступеня тяжкості тілесних ушкоджень.

Напряму не вказано, чи відноситься це поняття до загальнолюдських, естетичних, косметичних понять особливо у випадках вираженого порушення функції без суттєвих анатомічних недоліків - виражені асиметричні порушення міміки неврологічного характеру.

Ймовірно передбачається, що суд у своїх висновках може використовувати висновки експертів, що не $є$ лікарями (художників, спеціалістів в галузі образотворчого мистецтва, тощо). Однак це не відповідає вимогам «Правил» про встановлення тяжкості тілесних ушкоджень судово-медичними екстертами під час проведення експертизи у спеціалізованих медичних установах. Важливо пам'ятати, що встановлення тяжкості тілесних ушкоджень є однією з обов'язкових підстав для призначення судово-медичної експертизи (ст. 242 КПК України) [3]. Проведення будь яких інших видів експертиз: естетичних, портретних, психологічних 3 метою встановлення ступеня тяжкості тілесних ушкоджень законодавством напряму не передбачено.

З часу запровадження УПК в редакції 2013 року направлення матеріалів для додаткового розслідування на етапі судового слідства фактично неможливе. Це в межах дослідженого питання призводить до необхідності для судді здійснювати перекваліфікацію правопорушення в бік його обтяження. Останнє в свою чергу може викликати обгрутновані сумніви в юридичній бездоганності прийнятого рішення через виконання судом невластивої йому функції обвинувачення.

Як зазначалося вище, критерієм тяжкості тілесних ушкоджень є не знівечення обличчя, а незгладиме знівечення обличчя, тобто критерій вбачається нерозривним в межах медико-естетичної чи медико-юридичної конструкції. Вказану конструкцію неможливо вирішити одноосібно через іï граничність у різних галузях знань. Відповідно для іiі повного формулювання спеціальних знань немає ані у судово-медичного експерта, ані у представників судово-слідчих органів. Таким чином, принципово не зрозуміло хто є суб'єктом, який об'єднує медичні та немедичні поняття при оцінці виключно судово-медичного терміну оцінки ступеня тяжкості тілесних ушкоджень, та яким чином це робиться.

Можна констатувати, що встановлення незгладимого знівечення обличчя шляхом інтегрованого використання спеціальних знань та оцінки загально людських понять судово-слідчих органів та експерта $є$ надлишковим, адже це питання за певних обставин може бути вирішено експертним шляхом. Інакше це призводить до дублювання судом експертних функцій.

Через неодноразові звернення представників судово-слідчих органів до нашої установи, вважаємо необхідним запропонувати шляхи по уніфікації та врегулюванню вказаних аспектів. Через широкий розвиток пластичної та естетичної медицини в останній час в медичній спільноті сформувалася група спеціалістів, що володіє спеціальними знаннями та навичками для оцінки «краси», та естетичної привабливості обличчя людини. Підготовка цих спеціалістів відбувається на межі медицини та естетики, адже саме відчуття гармонії та краси (понять протилежних знівеченню) є передумовою надання пацієнтам спеціалізованої медичної допомоги в межах пластичної та естетичної медицини.

ВИСНОВОК. Ми переконані, що жоден фахівець, будь то судово-медичний експерт, слідчий чи суддя не може одноосібно вирішити питання чи є ушкодження знівечуючим, тому вважаємо за доцільне вирішувати досліджуване питання в межах комісійної або комплексної судово-медичної експертизи, принциповий склад якої визначається органом, що їі призначив із переліком фахівців, які мають необхідні естетичні уявлення для вирішення питання по суті. Постановою чи ухвалою представники судово-слідчих органів підтверджують повноваження комісії в межах питань, що вирішуються і відповідно перебирають на себе можливі претензії, щодо виходу членів експертної комісії за межі своєї компетенції. 


\title{
Література
}

1. Завальнюк А.X. Про необхідність внесення корективів у правила кваліфікації тяжкості тілесних ушкоджень /А.Х. Завальнюк//Український судово-медичний вісник. - Київ. - 2004. - № 2 (16).- С. 32-34.

2. Завальнюк А.X. Судово-медичні погляди на оцінку непоправних наслідків травмування обличчя / А.Х. Завальнюк, І.О. Юхимець, О.Ф. Кравець // Судово-медична експертиза. - 2016. - № 1. - С. 31-35.

3. Кримінальний і кримінально-процесуальний кодекси України /комп’ютерна верстка О. Мішутіної/К.: KM Publishing. - 2013. $-352 \mathrm{c}$.

4. Наказ від 17.01.1995р. № 6 МО3 «Про розвиток та вдосконалення судово-медичної служби України».

5. Закон України про адвокатуру та адвокатську діяльність від 05.07.2012 № 5076-VI.

\section{НЕИЗГЛАДИМОЕ ОБЕЗОБРАЖИВАНИЕ ЛИЦА - СУДЕБНО- МЕДИЦИНСКИЕ И ЮРИДИЧЕСКИЕ АСПЕКТЫ}

\author{
Л. Л. Голубович, А. Л. Голубович, П. Л. Голубович, М. Д. Зубко, \\ А. В. Куртев
}

Резюме. Быстротекущие изменения в экономической, политической и общественной жизни диктуют необходимость изменений и в правовой сфере, где работают не только юристы, но и судебно-медицинские эксперты, основная работа которых заключается в помощи судебно-следственным органам в установлении истины по конкретным делам, когда совершенны преступления против жизни, здоровья, чести или достоинства человека. В работе анализируются сложности, с какими сталкивается судебно-медицинский эксперт при определении степени тяжести причиненных телесных повреждений по критерию «неизгладимое обезображивание лица» и предлагаются пути устранения противоречий.

Ключевые слова: судебно-медицинская экспертиза, неизгладимое обезображивание лица, степень тяжести телесных повреждений.

\section{INDELIBLE DISFIGUREMENT OF FACE - FORENSIC AND LEGAL ASPECTS}

\section{L.L. Golubovich, A.L. Golubovich, P.L. Golubovich, M.D. Zubko,} A.V. Kurtev

Summary. Fleeting changes in economic, political and social life dictate the need for changes in the legal field, where the work is not only lawyers but also forensic medical experts, the main job is to help the judicial and investigative authorities in establishing the truth in specific cases where crimes against life, health, honor and dignity. In this article the difficulties with which forensic medical expert has faced during determining the degree of injuries under the criteria of "indelible disfigurement of face" and suggested ways to resolve the conflicts are analyzed.

Objective. Analyzation of forensic and legal approaches to solve questions and to find ways to resolve conflicts.

Conclusion. We are convinced that no specialist whether the forensic medical expert, an investigator or a judge can not single-handedly solve the problem of disfigurement of face, therefore consider it appropriate to solve the research question within the commission or a comprehensive forensic examination, a fundamental part of which is determined by the person that appointed it to the list of specialists who have the necessary aesthetic ideas to solve the issue on its merits. Order or decision of the representatives of the law enforcement bodies confirm the powers of the Commission within the issues to be addressed and, accordingly, take the possible claims, by the exit of members of the expert committee for the limits of its competence.

Despite the fact that our opinion may not be absolutely perfect, this publication we invite experts of forensic experts and lawyers to fruitful discussions and address the issues raised.

Keywords: forensic-medical examination, indelible disfigurement of face, the degree of injuries.

УДК 616-05:34

\section{ОСОБЛИВОСТІ УДЕНТИФКАЦЇ̈ ЛЮДИНИ ПО ПРИЖИТТЕВІЙ ОРТОПАНТОМОГРАМІ}

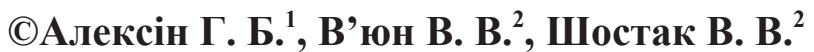 \\ ДЗ «Дніпропетровська медична академія МО3 України» ${ }^{1}$ \\ К3 «Дніпропетровське обласне бюро судово-медичної експертизи »ДОР»²
}

Резюме. Робота присвячена методу підготовки черепа людини для проведення ортомантомографії з метою порівняння 3 прижиттєвою ортопантомограмою для ідентифікації особи. В методиці запропонований простий економічний метод отримання якісних, пригідних для дослідження, ортопантомограм, без застосування балістичного гелю.

Ключові слова: ортопантомографія, зубощелепна система, череп людини, ідентифікація.

ВСТУП. Великомасштабні катастрофи, військові конфлікти, терористичні акти тягнуть за собою численні людські жертви та їх знеособлення, в зв'язку з чим ідентифікація особистості стає необхідною реальністю [1]. Ідентифікація особи в умовах воєнного конфлікту значно ускладняється після обстрілів з реактивної артилерії, 